\title{
People, Place, Public: The Public Art of Nic Moon
}

Robin Woodward

Keywords \#Nic Moon \#art \#human ecology \#installation \#new genre \#New Zealand \#public art \#sculpture

In the realm of public art, New Zealand artist Nic Moon's practice extends from permanent outdoor sculpture to ephemeral, site-responsive installations and staged public events. Such a range spans the trajectory of contemporary public art, a genre which theorists struggle to define categorically: historical precedents for public art offer no template for the present or for the future. Working in conjunction with mana whenua iwi, local government agencies, art institutions, museums, architects and the community, Moon creates large-scale object art as well as temporary and relocatable works, circumstantial installations, public artworks as utilities, and ephemeral art with a short life span. Her public art encompasses a broad spectrum of forms while speaking constantly of human ecology - the interdisciplinary study of relationships between people, our social systems and our environments. It is these relationships that underpin the work of Moon who, in common with new genre public artists internationally, is prepared to work outside the historical framework of public art to engage her audience in socially conscious, political art. 
New Zealand artist, Nic Moon, is the consummate public artist. In addition to her intimate, immersive gallery art, Moon's practice extends from large-scale outdoor sculpture to ephemeral, site-responsive installations. Such a range spans the trajectory of contemporary public art, a genre which theorists struggle to define. In New Land Marks Penny Bach generalises that public art is "art placed in public places and spaces' which are 'open to everyone to use and enjoy".' Public art theorist Cher Krause Knight retorts in response: "If only it were that easy!" and backs it up with Hilde Hein's memorable statement: "The sheer presence of art out-of-doors or in a bus terminal or a hotel reception area does not automatically make that art public, no more than placing a tiger in a barnyard would make it a domestic animal". In her turn, Patricia Phillips asserts that "art is public because of the kinds of questions it chooses to ask or address, and not because of its accessibility or volume of viewers".

Although there is no exact definition of public art, its most basic precept must be that it is "conceived for larger audiences, and placed to garner their attention; meant to provide an edifying, commemorative, or entertaining experience; and convey messages through generally comprehensible content". ${ }^{4}$ More specifically Seitu Jones contends that: "Public art documents our place in time by visually rendering issues, ideas, traditions, and history ... it identifies and comments on the challenges that affect us". ${ }^{5}$ Such a definition fits snugly with Nic Moon's philosophy: Moon's work is characterised by a sensitivity to the life of a place and its people.

However, this raises issues around permanence versus the short lived, impermanent installation. As Phillips explains, "There is a desire for a steadfast art that expresses permanence through its own perpetualness. Simultaneously society has a conflicting predilection for an art that is contemporary and timely, that responds to and reflects its temporal and circumstantial context". ${ }^{6}$ Nic Moon works across the entire spectrum. Within her oeuvre there is a body of work which is permanent large-scale object art. This can be an art programme developed in conjunction with architecture; Moon's collaboration with Jasmax architect Lars von Minden on Auckland's Ranui Public Library exemplifies this approach. Alternatively, it can be a utility situated in landscaped nature as is Raukura O Te Koroto (Te Koroto's Precious Feather) at Wenderholm Regional Park, just north of Auckland. While some works, such as The Cocoon, can be temporary because they are relocatable, at the other extreme, those made of less durable, even ephemeral materials, are intended for a short life span. One such work is Out of the Ashes (2007) (Figure 1), part of the biennial temporary installation programme at Connells Bay Sculpture Park on Auckland's Waiheke Island.

Set amidst a landscape of native bush in a coastal setting, Connells Bay is a 2.5 hectare permanent sculpture park populated with 35 large-scale works that showcase New Zealand's premier sculptors. ${ }^{7}$ The temporary programme was instigated to increase the range of works in the park and to offer something new each year for the repeat visitor. Each installation would remain in situ for just one summer season, from October to April. For the 2007 / 2008 season Moon's Out of the Ashes was a planting of native tree seedlings set inside the constructed remnants of campfires, and beneath a canopy of tall kanuka. To protect them and thus facilitate the regeneration of the native bush, Moon created shelters to protect and nurture the young trees. These shelters were inspired by woven Maori fishing nets and early colonial European dresses with hooped skirts. Each one was formed by fishing net shaped to fit a steel framework - rather like a one-person tent - and they were adorned with natural and manufactured items, small objects and locally scavenged materials that reflect the history of human settlement at Connells Bay. Fishing lures, seashells, sheep-

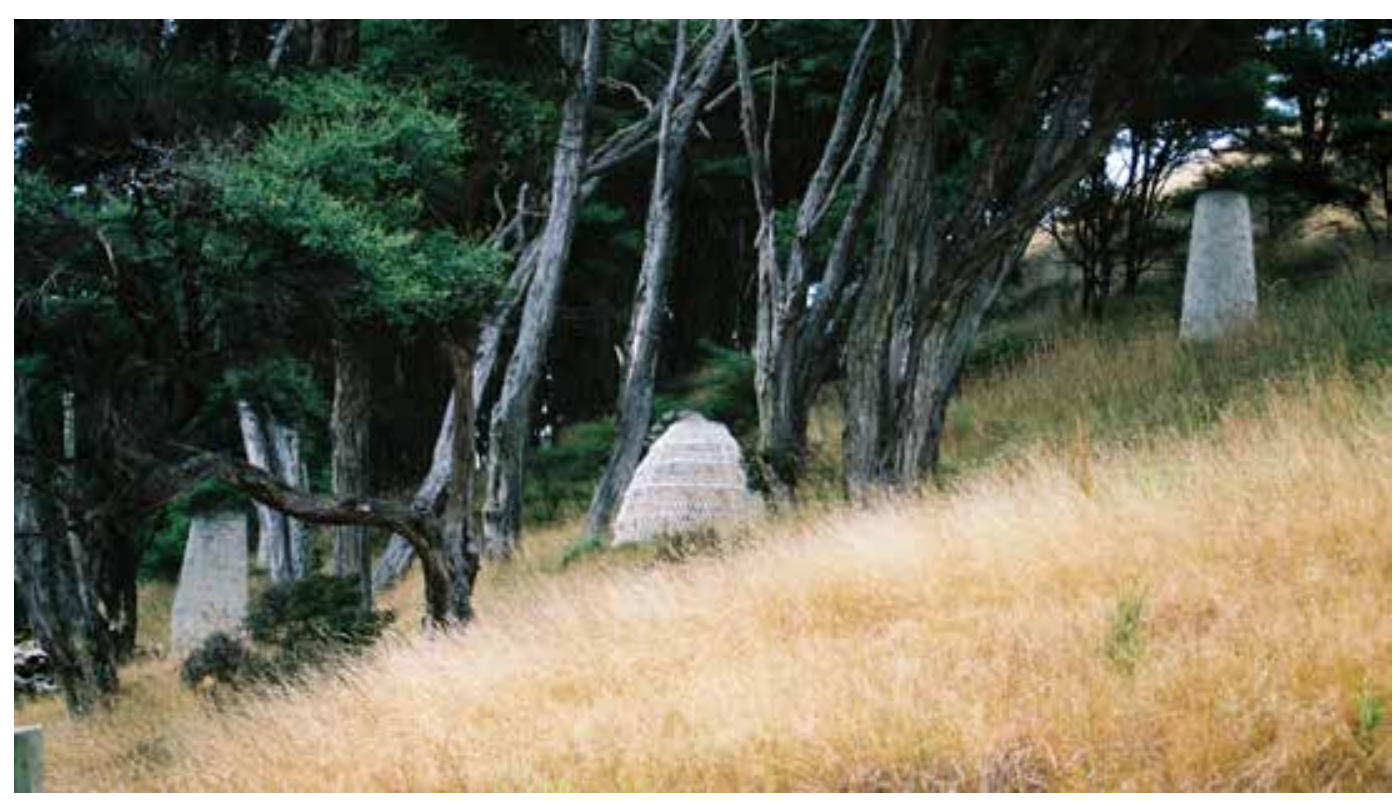

Figure 1. Nic Moon, Out of the Ashes, 2007, Waiheke Island, Auckland. 
shearing combs, sheep-dog whistles, tufts of fleece, baling twine and bullets were threaded onto the shelters. Such items are relics of Maori and European settler history and offer a visual narrative of human intervention in the land.

Out of the Ashes was a nursery, a small village of woven shelters providing the forest of the future with protection from grazing sheep. It could also be read as a contemporary archaeological site, one which reveals the processes of burning and reforestation initiated both by nature and by humankind. Moon does not impose a single meaning on some imagined homogenous audience, but keeps meaning "freeflowing, without privileging one level of understanding over another". ${ }^{8}$ However, the work speaks of the environmental history of Waiheke Island and contributes to the theme of human ecology which is a constant in the artist's oeuvre. Human ecology is the interdisciplinary study of relationships between people, our social systems and our environments. It is these relationships that underpin the work of Moon whose interest lies in aspects of physical and psychological survival, from both a micro (personal) and a macro (universal) perspective. ${ }^{9}$ Throughout colonial history, the indigenous vegetation of Aotearoa New Zealand has been systematically cleared to develop farmland. Here at Connells Bay, via the sculpture park's temporary installation programme, Moon replenishes the native flora at the same time as providing an artwork; her seedlings supplement the extensive programme of planting that has been carried out by John and Jo Gow. Simultaneously, by creating a 'village' of simple shelters, Moon critiques activity around the building of extravagant mansions and huge holiday homes on Waiheke Island and in many coastal regions. Thus the art object itself "is an 'expressive gesture' or quasi-voice, one that can interrupt the voices that thought they could easily enclose it within their discourses"..$^{10}$ In the context of the sometimes fraught artist / patron relationship, is this 'biting the hand that feeds you'? Maybe - but as David Salle reminds us 'Art Is Not a Popularity Contest'."

Out of the Ashes is an artwork in an arena of contesting voices. Moreover, it is an act of stealth. One could say that Out of the Ashes was still a work in progress when it was dismantled. While the structural part of this sculpture was removed, the trees planted by the artist remain, and are flourishing. A work that started as a temporary intervention in the landscape became quite 'at home' and integrated into the environment. It became permanent. And through its form the artwork circumvents what is a recurrent problem for permanent, site-specific art, that is, the difficulty in maintaining 'appropriateness to its site': a site may be drastically transformed after an artist first addresses it. ${ }^{12}$

In contrast to Out of the Ashes, artworks constructed out of natural materials can be ephemeral, and frequently 'return to nature'. This is exemplified by the work Moon created during her six week artist residency at Wenderholm Regional Park in 2008, when she used natural materials she found in the park to reference its bi-cultural social history. ${ }^{13}$ On part of the land Moon mapped out a housing subdivision and used materials traditional to Maori to build the frame of a shelter or whare. Another work was inspired by the colonial Victorian /

Edwardian Couldrey House in the park. Then, in the face of such human intervention in the land, Moon provided protection for the natural environment in the form of woollen wrappings for the fallen branches of young, native pohutukawa trees at Wenderholm. All of these works were left in situ at the end of the residency and, as they were made principally of natural materials endemic to the site, all eventually went back to the land.

A Royal Carpet (Figure 2) is subtly bicultural in its focus. On the carefully manicured, European-inspired lawn of Couldrey House Moon created a carpet of leaf skeletons from the native mahoe tree. The artwork is inspired by the lace curtains in this early colonial cottage which has been restored and is now used as an information and cultural centre, and includes a museum that focuses principally on the European history of the site. As the title implies, the vision for A Royal Carpet came also from stories about the visit to Wenderholm made by Queen Elizabeth II and the Duke of Edinburgh during their coronation tour in 1953. Leading up to the entrance of the house Moon created a walkway for royalty (Maori or English), carpeted by skeleton leaves she collected from the park. ${ }^{14}$ The lace-like patterns and colours of the leaves mirrored the lace curtains in the windows of Couldrey House. At this intersection of indigenous ecology and the colonial garden environment of Wenderholm Regional Park the 'indigenous lace' created out of the leaf skeletons of Aotearoa meets the 'introduced lace', brought to New Zealand by early European settlers. This is a temporary artwork inspired by the idea of building relationships in a nation that is founded on a bicultural Treaty.

For Pohutukawa Bones (Figure 3) at Wenderholm Moon used pohutukawa branches and twigs which had been dropped in a storm, wrapping them in red wool to create a ring of 'protection' for the roots of a sprawling pohutukawa tree. The colour of the protective wrapping makes reference to the 'bloodlines' or the genealogy of this young tree. 


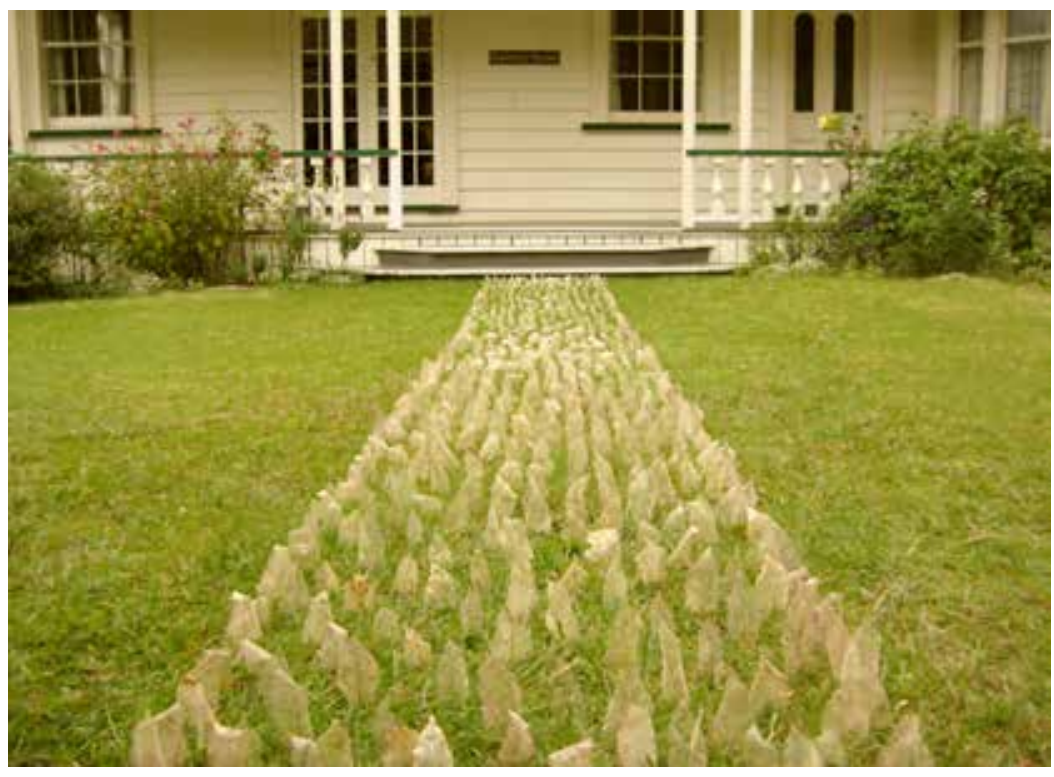

Figure 3. Nic Moon, Pohutukawa Bones, 2008, Wenderholm, Auckland.

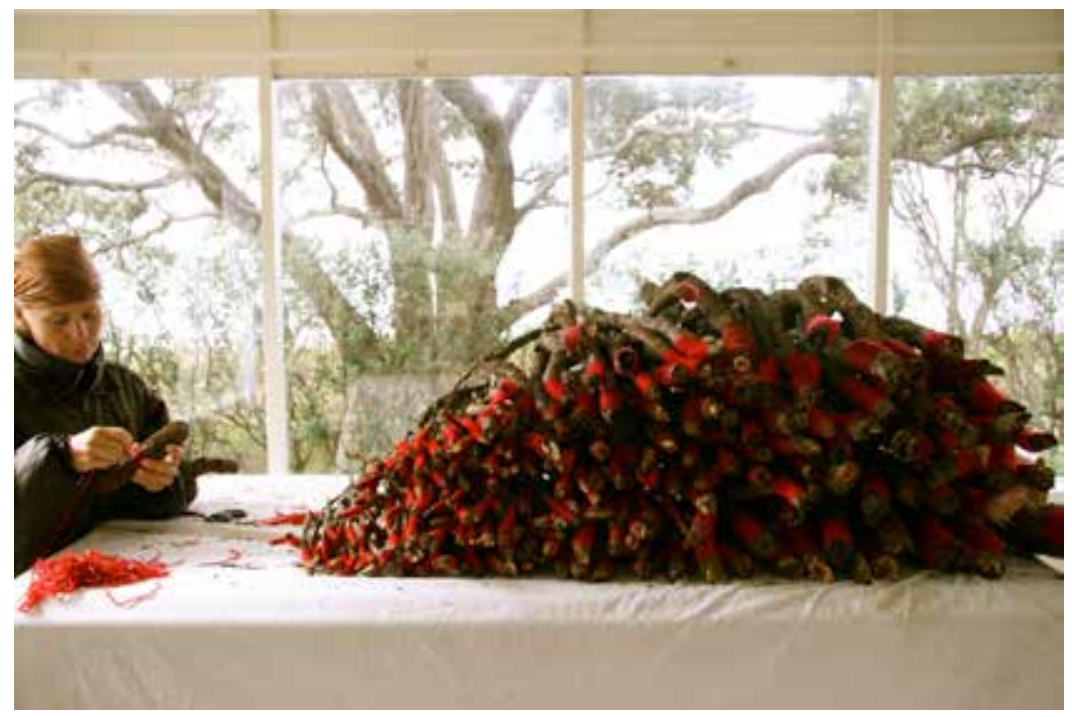

The oldest of these trees may have existed before the first humans arrived between 800 and 1000 years ago. In the early days of European colonisation, during the mid-nineteenth century, timber from the trees was in high demand for ship building, however, an early settler, Robert Graham, who arrived at Wenderholm in 1842, is said to have protected the old trees. ${ }^{15}$ Moon's installation is inspired by the work of the many people who, over the years, have followed in Graham's footsteps, safeguarding and caring for the grove of pohutukawa trees on the Wenderholm Peninsula. ${ }^{16}$ In another take on this work, Pohutukawa Bones is also inspired by the protection that the pohutukawa trees provide the public as they picnic and shelter here.

Moon's work at Wenderholm can be seen in the tradition of new genre public art which is populated by artists prepared to work outside the historical framework of public art. Their work is "a contemporary form of socially conscious, activist political art". ${ }^{17}$ This was the nature of the public art event staged by Moon and Whitespace Contemporary Art for Auckland's Artweek in 2012. Cow Dung Forest (Figure 4) was intended as a subversive act, sullying the glass entrance of a commercial urban art gallery with the excrement of New Zealand's most economically successful and environmentally contentious industry, dairy farming. Using a stencil process, Moon applied the pattern of a forest to the expansive, windowed exterior of Whitespace Contemporary Art gallery in Auckland's trendy, inner-city cafe district of Ponsonby. Then, over the course of a weekend, the public was invited to plunge their hands (gloves provided for the townies) into buckets of fresh cow dung and plaster the windows with a richly textured mass of human handprints. When the stencil was peeled off the windows it left the ghostly impression of an ancient forest which cast shadows into the gallery interior.

In Cow Dung Forest Moon explores new possibilities for the use of our nation's most abundant and under-utilized resource, cow dung, and involves the public in the creative process. Moon and Whitespace chose to treat the commercial art gallery not as a space of constricting tradition, but to "shift(s) the focus from artist to audience, from object to process". ${ }^{18}$ Through shared authorship of the artwork, Moon's intention was to raise awareness of the contamination of our drinking water supplies, and our recreational spaces (rivers) with nitrogen-rich cow effluent, "a by-product of our latte-drinking, dairy-productconsuming urban lifestyles". ${ }^{19}$ Cow Dung Forest was a response to a conversation Moon had in a small rural museum in Southland during her time as artist in residence for the William Hodges Fellowship in 2010. 


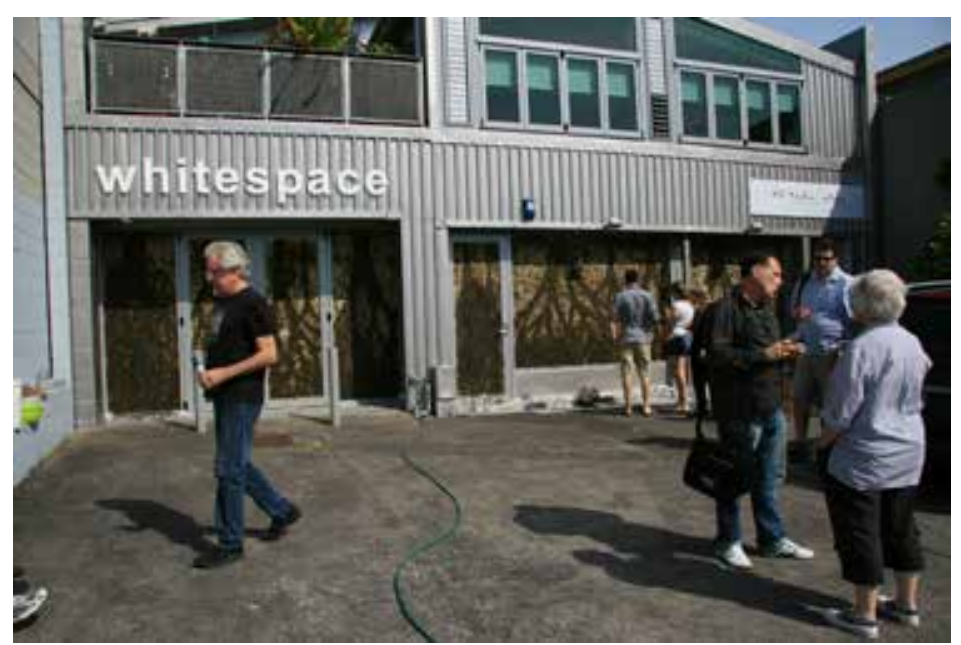

Her hosts revealed that they would not let their grandchildren swim in the local rivers because they were so polluted with cow effluent from local, industrial-scale dairy farms. Equally, they would not speak out against this appalling environmental management "because their small community depended on dairy farming for their economic survival." In Cow Dung Forest, the artist has become their 'voice'.

Moon's focus on environmental issues made her a natural contender for the commission to celebrate the 50th anniversary of Auckland's Regional Park network in 2016. The brief specified that this large-scale permanent artwork at Wenderholm should be functional: it should provide an amenity for the public. Such a precept has long been recognised as part of the twentieth century revival of public art in which art's functionality has "gained renewed emphasis with street furniture becoming standard public art fare". ${ }^{20}$ However, Moon's commitment to the tenets of public art runs deeper than this. She adheres to the belief that public art "identifies and comments on the challenges that affect us" ${ }^{\prime 21}$ and that it can "serve to mark the specifically local".22

Raukura O Te Koroto (2016) at Wenderholm served to mark the 'specifically local' and was also a protection or shelter for people visiting the park. It is a kererū (native wood pigeon) feather, a response to the long history of interdependence between bird-life and humankind in the sparse remnants New Zealand's coastal-forest. Auckland's regional parks provide a place of refuge and health for the local community while contributing to the global need to protect our atmospheric balance. The kererū is a crucial part of that ecological balance as it is the only remaining bird species that can swallow and distribute the seeds of the large coastal canopy trees. Yet the numbers of kererū have long been dwindling, a result of predation and the loss of habitat. Long-standing monitoring projects at Wenderholm are a crucial part of our national attempt to halt this decline and subsequently to save our coastal forests. The kererū needs us, and we need the kererū. Hence, Moon's kererū feather is a symbol of symbiosis, it represents the interdependence of nature and our communities in the precious remainders of our coastal forests. In concept, the feather of a kererū has floated gently down to earth from the trees above. In practice, the curve of its form becomes a roof under which a small group of people can find shelter from the sun and rain. The perspective Moon maintains is that of an observer of human processes. She sees herself as a conduit: her work is a commentary on human ecology, drawing out the things that might be lurking unseen or unacknowledged.

The process informing Raukura $\mathrm{O}$ Te Koroto was at the opposite extreme to the more intimate and immediate site-responsive, ephemeral counterparts that Moon made at Wenderholm in 2008. The brief for this permanent public sculpture called for a 'functional' artwork that satisfied the health and safety requirements for a structure in a public park, met the tight timeframe for financialyear-end budget allocations, and a project that could be mandated by lengthy, civic consent processes. The resulting 9 metre long, 3.6 metre wide, 3 ton feather-inspired shelter was created in consultation and collaboration with mana whenua, on-site conservation rangers, Auckland Council officers and administrators, arts advisers, local volunteers, structural engineers, fabricators, shipping companies and a crew of crane drivers involved in the installation. This type of commission does not leave much scope for the artist to respond to the process, or to make changes and adjustments once the drawings are submitted for consent purposes early in the design phase.

In theory, and in an academic reading, Raukura $\mathrm{O}$ Te Koroto ticks a list of pre-requisites for good public art:23 It is a robust, wellengineered work of art completed within budget, the process was consultative from the outset, and the work references its site, is an aesthetic enhancement, and also a public utility. Every public art project is, to some degree, an interactive process involving artists, architects, design professionals, community residents, civic leaders, politicians, approval agencies, funding agencies, and construction teams. The challenge of this communal process is to enhance rather 
than limit the artist's scope. Although time pressure related to the consent process meant this may not have been Moon's experience with Raukura $\mathrm{O}$ Te Koroto, working on the Auckland Council commission for the Ranui Public Library in 2014 was a lesson in a process embracing and fulfilling ideology.

Since the 1970s, libraries just like "airports and playgrounds, locations once likely to be disregarded or downgraded within traditional art historical parameters, ... take on great importance in a reconfigured 'canon'". ${ }^{24}$ This was part of the evolution of sites for public art. At the same time, the definition of 'the public' in public art has come under attention. The general public is now recognised as increasingly diverse, in fact "diverse, variable, volatile and controversial". ${ }^{25}$ Moreover, "art is most fully public when it sincerely extends emotional and intellectual access to its viewers". ${ }^{26}$ However "accessibility is not the parent of mediocrity; one does not have to 'dumb down' art or avoid challenging content to be accessible". ${ }^{27}$

The emergence of large-scale sculpture in conjunction with modern architecture can be "an attempt at ornament after the fact", 28 but with Auckland's Ranui Public Library nothing could be further from the case; from the outset the artist worked in conjunction with Jasmax architect Lars von Minden, and in consultation with local community groups. The brief for the artist and the architect was to create a building that provided the Ranui community with a heart or community epi-centre. Inspired by this, a forest-living room-campsite theme emerged. In the Living Room, at the centre of the new library building, Moon proposed a sculptural installation, The Great Forest (Figure 5). Drawing inspiration from environmental and human stories related to Ranui and the wider Waitakere area, she focused on bringing together aspects of ancient history, contemporary life and visions for the future. As a result, the main wall of the Living Room was transformed into an immense mythological forest inspired by the original kauri forest on the site. At the centre of the forest is a cascading shaft of light, which is 'peopled' with floating forest 'spirits', and at the foot of this towering forest is the fireplace around which the community gathers to draw warmth.

The use of a forest as the motif at the heart of the library is inspired by the wealth of resources that the ancient forests of the area offered to the earliest people who inhabited the region. An ancient forest can inspire stillness, contemplation, connection and imagination; these are also qualities that Moon associates with a library. Similarly, a forest provides shelter, refuge and health for the local community

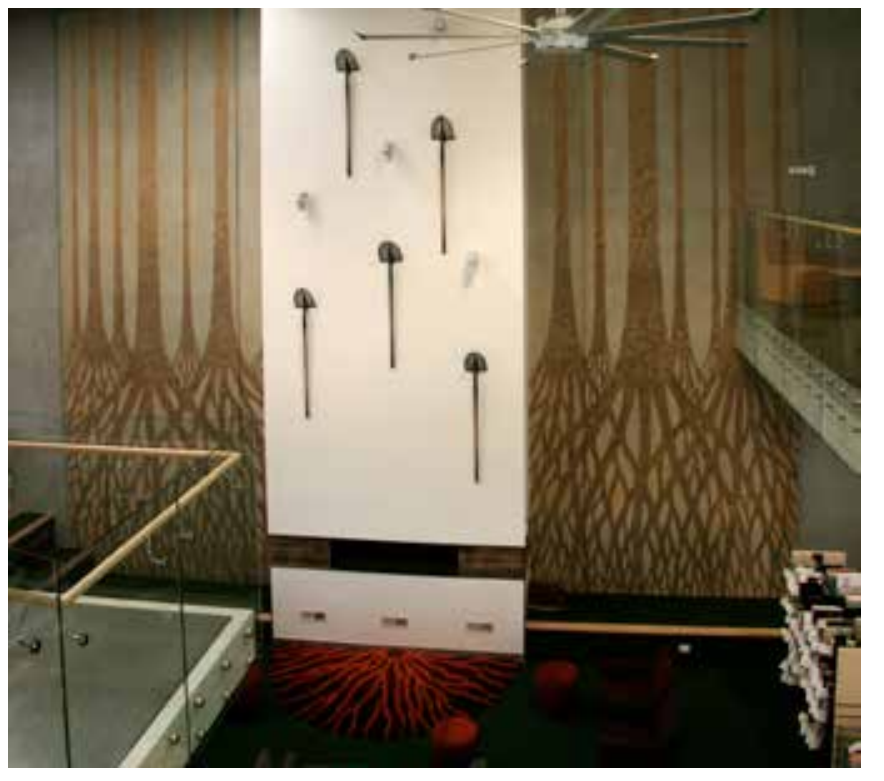

igure 5. Nic Moon and Jasmax The Great Forest, 2014, Ranui Library, Auckland. while contributing to the global need for environmental balance. The central focus of The Great Forest at Ranui is a series of old shovels incised with native plant, leaf-skeleton patterns. ${ }^{29}$ These shovels make reference to the farms, orchards and vineyards of the area's history and the contemporary community planting projects that are restoring local ecosystems. Lighting from above creates subtle shadows that radiate down the wall towards the fireplace. The walls either side of the shovels are adorned with a collaborative 'earth-forest painting'. This wall painting is inspired by the history of clay-based industries in the area. It acknowledges the many people, beginning with mana whenua iwi Te Kawerau a Maki, for whom the local earth has provided sustenance. According to Moon, it was clear from the outset that the diverse and multi-cultural Ranui community wanted to be involved in this project: such enthusiasm provided both inspiration and challenges for the artist and the building project managers. ${ }^{30}$ The community was invited to participate in creating the artwork, giving them the unique opportunity of early access to the building-site. To facilitate this, and to create the artwork, a towering nine-metre high scaffold complete with safety barriers suitable to accommodate the public, was erected inside the partially completed building. The scaffolding was placed in front of the two-storey central wall to which had been applied a stencil of immense tree silhouettes whose roots entwine to create an intricate web. Over the course of a weekend about four hundred members 
of the community became involved: they climbed the scaffolding, dipped their hands into pots of clay paint, and randomly placed their handprints on the stencilled wall, leaving their own personal imprint on the new building. ${ }^{31}$ By the end of the weekend the wall was covered with thousands of handprints, and when the stencils were removed, they left an image of a soft-focus, fossil-like clay forest that brings warmth and an earthy glow to the Living Room space.

On the 'forest' floor, in front of a gas-fire hearth is a large semi-circular woollen rug artwork, Volcano. ${ }^{32}$ This rug glows with the red and orange intensity of a campfire or a volcanic crater, and the pattern is inspired by the strong radiating root-system of a pohutukawa tree. It also makes reference to the huge Waitakere volcano that erupted in the sea to the west of the present Waitakere Ranges which are composed of the uplifted and eroded eastern slopes of that ancient volcano. ${ }^{33}$ Couches around the fireplace are an invitation to the community to gather round the 'campfire' to relax, to read, to share stories and to soak up the inspiration offered in the library. The forest theme continues on the exterior of the library where it has been integrated into a huge corten steel canopy that surrounds the upper section of the building: this aspect of the project was designed in collaboration with the architect. Sections of the steel are cut with forest canopy imagery taken from the artist's drawings, which creates a dappled light inside the building. The steel references the tools used to cut the original forest and transform the land into farms, orchards and gardens.

Through a process of consultation and community participation, at Ranui Library a space was created in which the community feels connected, empowered and inspired; the public has a sense of ownership of its new library and the public art project at its heart. The community and its values and concerns are seen as the context, and the art serves to enrich the lives of those who participated. This is community-specific art. ${ }^{34}$

Erika Doss, however, reminds us that the form and content of public art are "dependent on a variety of cultural and social relationships and subject to the volatile intangibles of multiple publics and their fluctuating interests and feelings". ${ }^{35}$ "What is thought to be an appropriate aesthetic expression of a society's values during one period of history can appear dated in the next. What one group cherishes, another can find offensive". ${ }^{36}$ Moon accommodates such variables in The Cocoon (2015) (Figure 6), which, as a temporary and relocatable public artwork, circumvents the fact that permanent works

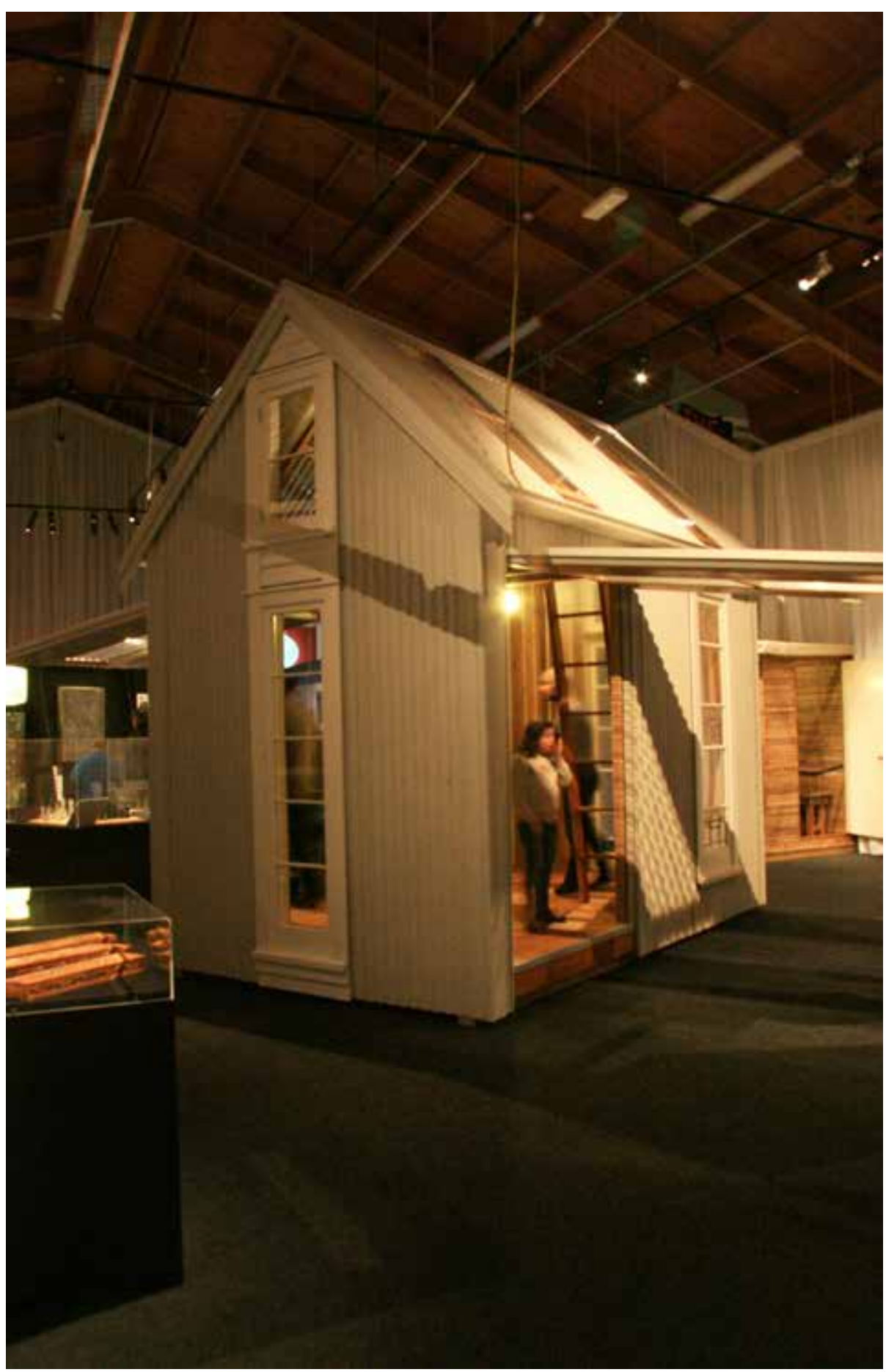

Figure 6. Nic Moon and Lyn Russell, The Cocoon, 2015, Canterbury Museum, Christchurch. 
are "likely to have difficulty gaining support, and must renegotiate their relationships with changing publics over time". ${ }^{37}$ The Cocoon is a prototype for a ten square-metre backyard studio which can be readily dismantled and rebuilt, responding to the need for adaptability in our increasingly changeable environments. It is made entirely from materials salvaged in the wake of the Christchurch earthquakes and is the result of collaboration between Moon and architectural designer Lyn Russell. Together they designed this space of transformation, inspired by the resilient life cycle of a butterfly: by opening up, The Cocoon expands to become a studio or workshop, then by re-cocooning inwards it becomes a place of stillness and retreat.

The Cocoon was created as part of the Whole House Reuse project which attempted to carefully deconstruct and catalogue every part of a single home, the house at 19 Admirals Way, Christchurch. The materials were then made available to artists and designers to create 'useful' objects. This project was a response to the trauma and loss experienced in the 2011 Christchurch earthquakes, and was designed to draw attention to the variety of material in a house as well as the waste that is being generated by the Christchurch clean up. It was initiated as a counterpoint to the 10,000 homes, churches and commercial buildings that were smashed to pieces by bulldozers in the aftermath of the city's earthquakes. The Cocoon is one of approximately 400 useful objects, made from the materials retrieved from just this one condemned 'red zoned' building. The Whole House Reuse exhibition at the Canterbury Museum in 2015 involved over 250 people and included archival footage of the deconstruction of the house at 19 Admirals Way as well as interviews with the Buxton family, the last owners and residents of the house.

At the outset, Moon and Russell were motivated by a series of photographs of the mountain of building waste at the Burwood Resource Recovery landfill site in Christchurch: the scale of this agglomeration reduced a towering digger to the scale of an ant. In the rush to clear land in Christchurch for a speedy rebuild, entire homes, complete with furniture and personal effects, were demolished. A wealth of timber from our ancient forests was trashed, as were other valuable building materials that were not considered economically viable to salvage. The details of children's toys, books, and mattresses crushed amongst timber and roofing iron was disturbing to witness. ${ }^{38}$ The Whole House Reuse project acknowledged the journey of trauma recovery experienced by many, and it wanted also to inspire a different approach to salvage and encourage the reuse of our precious resources. In the contemporary Western world the abundance of used building materials in our neighbourhoods is often overlooked as not economically viable, and is destined for landfill sites. Yet, in their marks and scars, these materials hold the tissue memory of our rich and vibrant human and environmental stories.

Akin to The Cocoon, public art projects internationally have been realised through recycling of materials. From 2010 to 2015 Jun Kitazawa repurposed a vacant retail store in suburban Tokyo to create Living Room. This was organized into a 'living room' open to all, where local residents were invited to deposit unwanted furniture. The space also became a site of exchange serving the community as a place of social gathering. ${ }^{39}$ In 2009, Chicago, artist Theaster Gates purchased the home adjacent to his own: he restored it using recycled and salvaged materials, and deposited 14,000 art and architecture books from a recently closed local bookstore, and 60,000 slides donated by the University of Chicago's art history department. This project had a specific, local, social agenda - to counter an exodus from a South Side neighbourhood..$^{40}$ Evaluations of these projects have considered, among other things, "the danger of equating urban sculpture with urban renewal" ${ }^{41}$ One of the most well-known projects open to this criticism was the interdisciplinary public art programme at MacArthur Park in downtown Los Angeles during the 1980s. Over a four year period art forms by contemporary artists were placed in that rundown urban space with the express intention of engaging with the disenfranchised, and invoking social change. ${ }^{42}$ Some public art theorists warn against such a move. Phillips states "Public art has been too often applied as a modest antidote or a grand solution, rather than perceived as a forum for investigation, articulation, and constructive reappraisal". ${ }^{43}$

These international examples are site-specific artworks intended for a designated community. In contrast, Moon's work, being dismantlable and relocatable has a broader audience. In the past three years it was built in Nelson, exhibited in Christchurch, and Nelson, and now it is being used as a design studio. For each outing The Cocoon was built, and then after each showing, was carefully deconstructed, packed and prepared for its next location. In this it is distinctive from other public artworks that employ recycled materials, and also from other relocatable, temporary artworks which are effectively franchises that travel the international circuit, hired out for set lengths of time, often in conjunction with institutional bi- or triennials. Many, such as Ujino Munituru's Dragon Head in Auckland's Aotea Square in 2011, rely on spectacle for effect. ${ }^{44}$ However Fred Evans cautions against such 
public art, warning that "the work's aesthetic must not be a 'spectacle' that mutes or trivializes the incitement the work might give to new thought, action or collective formation". 45

Definitions of public art and what is recognised as 'the public' are constantly evolving. Historical precedents for public art offer no template for the present or for the future, but it is now well recognised that public art does not have to last forever. "It does not have to cast its message to some unmistakeable but platitudinous theme that absolutely everyone will get; it does not have to mark or make a common ground. . . . It must rely on its flexibility, its adaptability to be both responsive and timely, to be both specific and temporary". 46 Yet for many artists and arts administrators, the success of public art initiatives is calculated by the ability to place works permanently. "Permanency confers status, indicating that a work is so good it deserves to be seen and preserved for generations". ${ }^{47}$ Countering this, ephemeral artworks "prompt no concern that an undesirable neighbor is being foisted upon the public for all time; rather, their work offers a temporary interjection into a given environment, makes its statement and then moves on and out". 48

As public art theorists continue to see-saw through their definitions of the genre, one thing is clear: "For any meaningful understanding of public art, it must be viewed in the complex matrix in which it is conceived, commissioned, built, and, finally, received". ${ }^{49}$ Public art is a reflection of how we see the world - the artist's response to our time and place combined with our own sense of who we are. Through a broad spectrum of art forms Nic Moon speaks constantly of the relationships between people, social systems and the environment. Through her socially conscious, political statements she ventures beyond the historical framework of public art in her critique of us, our time, our place.

\section{REFERENCES}

Nic Moon, interview by the author, Auckland, March 26, 2018

Bach, Penny Balkin. New Land Marks. Washington DC: Editions Ariel, 2001.

Bingler, Steven. "The MacArthur Park Experiment 1984-1987." Critical Issues in Public Art Content Context and Controversy. Harriet Senie and Sally Webster (eds.). 1992. New York: HarperCollins. 270-279.

Elsen, Albert. "What We Have Learned about Modern Public Sculpture: Ten Propositions." Art Journal 48, no. 4 (Winter, 1989): 291-297.

Evans, Fred. "The Dilemma of Public Art's Permanence." Public Art Dialogue 6, no. 1 (2016): 58-81.

Hayward, Bruce. "Geology of the West." West: The History of Waitakere. Finlay Macdonald and Ruth Kerr (eds.). 2009. New Zealand: Random House: 7-22.

Jones, Seitu. "Public Art That Inspires Public Art That Informs." Critical Issues in Public Art Content, Context and Controversy. Harriet Senie and Sally Webster (eds.). 1992. New York: HarperCollins. 280-286

Kwon, Miwon. One Place after Another. Site Specific Art and Locational Identity. Cambridge, Massachusetts: MIT Press,

Phillips, Patricia. "Temporality and Public Art." Critical Issues in Public Art Content, Context and Controversy. Harriet Senie and Sally Webster (eds.). 1992. New York: HarperCollins. 295-304.

Salle, David. How to See: Looking, Talking, and Thinking about Art. New York: W. W. Norton and Company, 2016.

Senie, Harriet. Contemporary Public Sculpture: Tradition, Transformation, and Controversy. New York: Oxford University Press, 1992.
Senie, Harriet "Re-interpreting the Canon." Public Art Dialogue 1, no. 1 (2011) 1-4.

Senie, Harriet, and Sally Webster (eds.) Critical Issues in Public Art Content, Context and Controversy. New York: HarperCollins, 1992.

Connells Bay Sculpture Park. www.connellsbay. co.nz [accessed January 10, 2018].

Dilana Rugs. http://dilana.co.nz [accessed February 12, 2018]

Encouraging Temporary Public Art Auckland Design Manual. www.aucklanddesignmanual.co.nz design-thinking/public_art/public_art.../encourage [accessed April 1, 2018]

Kitazawa Office Yokumo 04 Living Room. http:// www.junkitazawa.com/04-livingroom.html [accessed January 14, 2018].

Living Room 2011 Programme Curator Work The Big idea Arts. https://www.thebigidea.nz/ work/159169-living-room-2011-programme-curator [accessed April 1, 2018].

Nic Moon. www.nicmoon.co.nz [accessed December 1, 2017].

Wenderholm - Regional parks - Auckland Council. regionalparks.aucklandcouncil.govt.nz/Wenderholm [accessed February 12, 2018].

Theaster Gates Dorchester Project Art in the Public Sphere. https://artpublicsphere.wordpress. com/2015/07/28/theaster-gates-dorchester-projects [accessed January 14, 2018]

Whitespace Contemporary Art. www.whitespace. co.nz/artists/nic-moon.aspx [accessed December 10, 2017]. 


\section{ENDNOTES}

Penny Balkin Bach, New Land Marks (Washington DC: Editions Ariel, 2001), p.153.

2 Cher Krause Knight, Public Art Theory, Practice and Populism (Oxford, United Kingdom Blackwell Publishing, 2008), p.viii.

3 Patricia Phillips, "Temporality and Public Art" in Harriet Senie and Sally Webster (eds.), Critical Issues in Public Art Content, Context and Controversy (New York: HarperCollins, 1992), p.298.

4 Knight, p.1.

5 Seitu Jones, "Public Art That Inspires Public Art That Informs" in Harriet Senie and Sally Webster (eds.), Critical Issues in Public Art Content, Context and Controversy (New York: HarperCollins, 1992), p.282.

6 Phillips, p.295

7 Connells Bay Sculpture Park, the vision of John and Jo Gow, was established in 1998. Moon's Out of the Ashes was the third in a series of five commissions for the temporary installation programme which was initiated in 2005 and ran until 2010. For Connells Bay Sculpture Park see www.connellsbay.co.nz.

8 Knight, p.25.

9 Unless otherwise stated, all references to $\mathrm{Nic}$ Moon's opinions derive from conversations between the author and the artist between December 2017 and March 2018. For further information see www.nicmoon.co.nz and www. whitespace.co.nz/artists/nic-moon.aspx.

10 Fred Evans, "The Dilemma of Public Art's Permanence," Public Art Dialogue 6, no. 1 (2016)

11 This is the title of David Salle's commencement address delivered at the New York Academy of Art in 2011. Reproduced in David Salle, How to See: Looking, Talking, and Thinking about Art (New York: W. W. Norton and Company, 2016), p.249.

12 Harriet Senie discusses this in Harriet Senie, Contemporary Public Sculpture: Tradition, Transformation, and Controversy (New York: Oxford University Press, 1992), p.230.

13 Moon was the inaugural artist in residence in this Auckland Regional Council initiative.

14 Visitors to the park respected this work, and did not walk on it. Eventually nature took its course, and the wind and the rain dismantled A Royal Carpet.
15 regionalparks.aucklandcouncil.govt.nz/Wenderholm [accessed February 12, 2018]

16 Over the years, seedling pohutukawa trees have been planted at Wenderholm to ensure the continuation of this protected grove. New seedlings are now being grown and planted from the seed of the ancient pohutukawa trees on this peninsula.

17 Miwon Kwon, One Place after Another. Site Specific Art and Locational Identity (Cambridge, Massachusetts: MIT Press, 2002) p.106.

18 lbid.

19 Nic Moon, interview by the author, Auckland, March 26, 2018.

20 Knight, p.28.

21 Jones in Senie and Webster, p.282.

22 Harriet Senie, "Re-interpreting the Canon," Public Art Dialogue 1, no. 1 (2011): 1.

23 Albert Elsen provides just such a list in Albert Elsen, "What We Have Learned about Modern Public Sculpture: Ten Propositions," Art Journal 48, no. 4 (Winter, 1989): 291-297.

24 Senie, Public Art Dialogue, p.2.

25 Phillips, p.304.

26 Knight, p.23.

27 Ibid.

28 Harriet Senie and Sally Webster (eds.), Critical Issues in Public Art Content, Context and Controversy (New York: HarperCollins, 1992), p.xiii.

29 The leaves were sourced from trees in local forests.

30 Nic Moon, interview by the author, Auckland, March 26, 2018.

31 Made from locally gathered earth pigments, the clay paint was prepared in collaboration with residents from the neighbouring Earth song Permaculture Community.

32 The rug is hand-tufted, $100 \%$ wool. It was designed by Moon and made in collaboration with Dilana Rugs. For Dilana Rugs see http:// dilana.co.nz.

33 Bruce Hayward, "Geology of the West," in Finlay Macdonald and Ruth Kerr (eds.), West: The History of Waitakere (New Zealand: Random House, 2009), p.8.

34 Miwon Kwon discusses the distinctions between site-specific art and community-specific art in Kwon, p.109-110.
35 Erika Doss quoted in Evans, p. 58.

36 lbid.

37 Knight, p. 140

38 Nic Moon, interview by the author, Auckland, March 26, 2018.

39 Jun Kitazawa Office Yokumo 04 Living Room http://www.junkitazawa.com/04-livingroom. html [accessed January 14, 2018].

40 Theaster Gates, Dorchester Project Art in the Public Sphere https://artpublicshere.wordpress.com/2015/07/28/theaster-gates-dorchester-projects [accessed January 14, 2018].

41 Senie and Webster, p.248.

42 See Steven Bingler, 'The MacArthur Park Experiment 1984-1987' in Harriet Senie and Sally Webster (eds.), Critical Issues in Public Art Content, Context and Controversy (New York: HarperCollins, 1992), p.270-279.

43 Phillips, p.296.

44 Ujino Munituru's Dragon Head was part of the Auckland City Council's ten day Living Room festival which ran from 8-17 April, 2011. Documentation of the Living Room temporary art project was previously available on the Auckland Council website but is no longer accessible. The following sites contain some relevant reference: Living Room 2011 Programme Curator Work The Big idea Arts https://www. thebigidea.nz/work/159169-living-room-2011programme-curator [accessed 1 April, 2018] Encouraging Temporary Public Art Auckland Design Manual. www.aucklanddesignmanual. co.nz/design-thinking/public_art/public_ art /encourage [accessed 1 April, 2018].

45 Evans, p.65.

46 Phillips, p.303.

47 Knight, p.140.

48 Ibid, p.141.

49 Senie and Webster, p.xi. 